\title{
Detection of Extended Spectrum Beta-lactamase (ESBL) Producing Gram Negative Bacteria from Clinical Specimens of Sir Salimullah Medical College and Mitford Hospital
}

\author{
Shikha Paul ${ }^{1}$, SanyaTahmina Jhora ${ }^{1}$, Prashanta Prasun Dey ${ }^{2}$, Bilkis Ara Begum ${ }^{3}$ \\ ${ }^{1}$ Department of Microbiology, Sir Salimullah Medical College, Dhaka. ${ }^{2}$ Department of Endocrinology, Kumudini \\ Hospital, Tangail. ${ }^{3}$ Department of Microbiology, National Institute of Cancer Research and Hospital, Dhaka
}

Submitted on: 20 February, 2015. Accepted on: 15 May, 2015

\begin{abstract}
:
Detection of Extended spectrum beta lactamase (ESBL) enzyme producing bacteria in hospital settings is vital as ESBL genes are transmissible. This study was carried out to determine the distribution of ESBL producing gram negative isolates at a tertiary care hospital in Dhaka city which deals with the patients hailing from relatively low socioeconomic status.Onehundred and twenty four gram negative bacteria isolated from different clinical specimens from outpatient and inpatient departments of Sir Salimullah Medical College and Mitford Hospital (SSMC \& MH) were tested for ESBL by E test ESBL method in the department of microbiology of Sir Salimullah medical college (SSMC) from March 2013 to August 2013.Out of 124 gram negative bacteria 69 (55.65\%) were positive for ESBL. Among the ESBL producers, Esch.coli was the highest $(46.38 \%)$ which was followed by Serratia spp (11.59\%), Enterobacter spp (10.14\%), Proteus spp, (8.70\%), Acinetobacter spp.(7.24\%) and Klebsiella spp.(5.79\%). Out of 32 Esch.coli isolated from outpatient department, $10(31.25 \%)$ were positive for ESBL. On the other hand out of 27 Esch. coli isolated from inpatient department, 22 $(81.48 \%)$ were positive for ESBL. The difference was statistically significant $(p<0.001)$. So the present study reveals that the distribution of ESBL producers is more among the hospitalized patients than the patients of the community.
\end{abstract}

Key word: Bangladesh, ESBL, Gram Negative Bacteria.

\section{Introduction:}

Gram negative bacteria intrinsically can produce both chromosomal and plasmid mediated beta lactamases enzymes due to selective pressure created by beta lactam substances produced by soil organisms. TEM-1 was the 1 st plasmid mediated beta lactamase enzyme described in early 1960. Subsequently extended spectrum beta lactamases (ESBLs) are identified $^{1}$. ESBLs are 2be group enzymes of Bush-JacobyMedeiros classification and some of group $2 d$ enzymes which has similar functional properties like group 2 be enzymes ${ }^{2}$.These enzymes are produced by members of Enterobacteriaceae such as Esch. coli, K. pneumoniae, Enterobacter spp., Citrobacter spp., Proteus spp, Morganella morganii, Serratia marsescens, Shigella dysenteriae, and other Gram negative bacteria like Pseudomonas aeruginosa and Acinetobacter baumanii ${ }^{1}$.

ESBLs are usually TEM, SHV and CTX-M gene mediated

$\triangle 0$ Correspondence:

Dr. Shikha Paul

Associate Professor

Department of Microbiology, SSMC, Dhaka

Email:shikhapaul2013@gmail.com

Phone:01732806772 beta lactamases ${ }^{3}$. Since 1995 rapidly proliferating CTX-M gene mediated ESBLs are taking upper hand over TEM or SHV gene mediated enzymes due to its greater ability to spread. Gram negative bacteria obtain CTX-M genes from environmental Kluyvera species ${ }^{4}$.CTX-M enzymes hydrolyze cefotaxime better than ceftazidime. Many hydrolyze cefepime as well ${ }^{5}$.Same organism can harbor many types of enzyme along with other new beta lactamase like AmpC-type beta lactamases, carbapenemases, which change antibiotic susceptibility pattern ${ }^{3}$. These ESBLs are efficiently capable of hydrolyzing penicillins, early ceplalosporins such as cephaloridine and cephalothin except cephamycins, the oxyimino group containing cephalosporins like cefotaxime, ceftazidime, and monobactam and are usually inhibited by beta-lactamase inhibitors such as clavulanicacid, sulbactam, and tazobactam ${ }^{3,5}$. In addition ESBLs genes are frequently intermingled with other antibiotic resistance genes such as tetracycline, aminoglycosides, trimethoprim, sulphonamide, chloramphenicol and quinolones making them multidrug resistance ${ }^{4}$. High prevalence of ESBL producers are documented from all over the country. Prevalence of ESBLs differs significantly geographically and depends on various factors ${ }^{6}$. Enterobacteriaceae are the most common group of gram-negative rods isolated in clinical laboratories, ${ }^{7}$ hence 
detection of ESBL production by Enterobacteriaceae and other gram negative bacteria has paramount importance to ensure appropriate antibiotic treatment. With this view this study was designed to find out the distribution of ESBL producing bacteria isolated from different clinical specimens of Sir Salimullah Medical College and Mitford Hospital in Dhaka city of Bangladesh.

\section{Methods:}

Clinical specimens were collected from the patients attending the microbiology laboratory of Sir Salimullah Medical College (SSMC) from outpatient and inpatient department, Dhaka, during the period of March 2013 to August 2013.Total 124 gram negative bacteria were isolated and identified from different biological samples such as urine, pus, wound swab, stool, blood and High vaginal swab(HVS). Samples were collected following standard procedures. MacConkey's agar and blood agar media were used for the primary isolation of the bacteria. Identification of particular gram negative bacteria was done by gram staining, observing colony morphology, oxidase test, inoculation into Triple sugar iron (TSI), Motility indole urea (MIU) and Simmons citrate agar media. ESBL producing bacteria was detected by Screening test, Double disc synergy test (DDST) and E test ESBL method. E test ESBL method was taken as gold standard. Klebsiella pneumoniae ATCC 700603 was used as reference strain for ESBL positive control. The strain of Esch.coli, which was sensitive to ceftazidime, ceftriaxone, cefotaxime and aztreonam was used as negative control.

Screening test ${ }^{8,9}$ :

Standard inoculum of bacterial suspension matched to 0.5 McFarland was made and Muller Hinton agar (MHA) plate was inoculated properly with bacterial suspension. Ceftazidime $(30 \mu \mathrm{g})$, Ceftriaxone $(30 \mu \mathrm{g})$, Cefotaxime $(30 \mu \mathrm{g})$ and Aztreonam $(30 \mu \mathrm{g})$ discs (Oxoid, England) were placed onto MHA plate and incubated overnight at $37^{\circ} \mathrm{C}$. When inhibition zone of any isolate to Ceftazidime $\leq 22 \mathrm{~mm}$ or Aztreonam $\leq 27 \mathrm{~mm}$, or Cefotaxime $\leq 27 \mathrm{~mm}$ or Ceftriaxone $\leq 25 \mathrm{~mm}$ alone or in combination was found then the isolate was taken as screening test positive.

Double disc synergy test (DDST) $)^{8,9}$ :

The MHA plate was inoculated with bacterial suspension matched to 0.5 McFarland. Ceftazidime $(30 \mu \mathrm{g})$, Ceftriaxone $(30 \mu \mathrm{g})$, Cefotaxime $(30 \mu \mathrm{g})$ and Aztreonam $(30 \mu \mathrm{g})$ discs were placed $15 \mathrm{~mm}$ distance centre to centre from amoxiclav disc (20mg amoxicillin and 10mg of clavulanic acid) which was placed at middle. Any extension of inhibition zone of antimicrobial discs (one or more) towards amoxiclav disc confirmed the presence of ESBL.
E test ESBL Method ${ }^{8,9}$ :

Triple ESBL detection (Ezy MICTM) strip was used. The upper half of this phenotypic ESBL detection strip had ceftazidime, cefotaxime and cefepime (mixture) plus beta lactamase inhibitor mixture (clavulanic acid and tazobactum) with highest concentration tapering downwards. Whereas lower half was similarly coated with ceftazidime, cefotaxime and cefepime (mixture) in a concentration gradient in reverse direction. Standard inoculum of bacterial suspension matched to $0.5 \mathrm{McFarland}$ was made and Muller Hinton agar plate was inoculated properly with matched bacterial suspension. With the help of applicator one ESBL detection strip was placed on one MHA plate. Plates were transferred in the incubator at $37^{\circ} \mathrm{c}$ for 24 hours. ESBL producing strain was confirmed either when the ratio of the value obtained for combination of antibiotic mixture plus beta lactamase inhibitor mixture and antibiotic mixture alone was greater than or equal to eight or presence of phantom zone that is no inhibitory zone was formed at antibiotic mixture side but inhibitory zone was found at combination of antibiotic mixture plus beta lactamase inhibitor mixture side.

\section{Result:}

Total isolated gram negative bacteria was 124 and the most frequently isolated bacteria was Esch.coli. (Figure1). Out of 59 Esch.coli, 32 (54.24\%) was confirmed as ESBL producers by E test ESBL method (Table 1). Significantly highest (81.48\%) percentage of ESBL producing Esch.coli had been identified from inpatient department (IPD) and only $31.25 \%$ ESBL producing Esch.coli was detected from outpatient department (OPD) (Table1). Urine was the most common specimen. Sixty three percent of total Esch.coli was isolated from urine samples (Figure 2). Out of 15 Esch.coli isolated from urine sample of inpatient department, 13(86.67\%) were ESBL producers and $8(36.36 \%)$ were ESBL producers among 22 Esch.coli isolated from urine of outpatient department (Figure 3). Difference of ESBL production by Esch.coli between inpatient and outpatient department was statistically significant. Next to Esch coli, Enterobacter spp numbered second, Proteus spp. numbered third, Pseudomonas spp and Serratia spp numbered fourth position among 124 isolations (Table 2). ESBL producing Enterobacter spp, were $7(43.75 \%)$ out of 12 , ESBL Proteus spp. were 6(54.55\%) among 11 and ESBL producing Pseudomonas spp was $1(12.50 \%)$ out of 8, ESBL producing Serratia spp were 08(100\%) , ESBL producing Klebsiella spp, were 04 (57.14\%) among 7 and ESBL producing Acinetobacter spp were $5(83.33 \%)$ out of 6 (Table-2). In all strains number of inpatient ESBL producing isolates were higher than outpatient department (Figure-3). 32 (54.24\%) ESBL Esch.coli out of 
total 59 Esch. coli, and isolated $43.75 \%$ of Enterobacter spp, $54.55 \%$ of Proteus spp., and $57.14 \%$ of Klebsiella spp were ESBL producers. (Table 2),

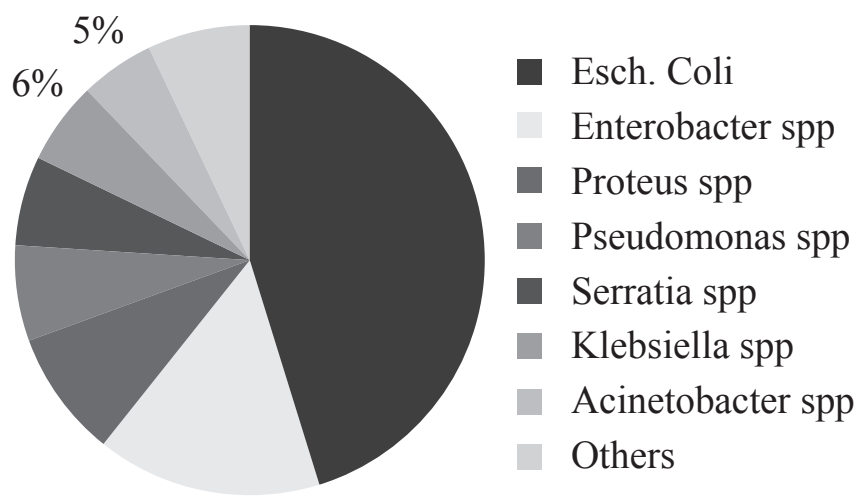

Figure-1: The Percentage of isolated bacteria from different clinical specimens

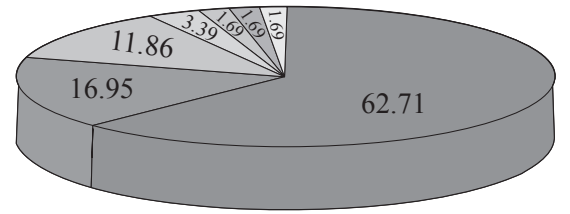

Urine $(63 \%)$

- Stool $(17 \%)$

Wound swab $(12 \%)$

Pus $(3 \%)$

High vaginal swab $(1.6 \%)$

Blood (1.6\%)

Fig 2: The percentages of Esch.coli isolated from various specimens

Table 1: ESBL producing Esch.coli detected by different methods

\begin{tabular}{|c|c|c|c|c|c|c|c|c|}
\hline \multirow[t]{2}{*}{ Tests } & \multicolumn{3}{|c|}{$\begin{array}{l}\text { Esch.coli from Inpatient } \\
\text { department subjected to } \\
\text { ESBL detection test }\end{array}$} & \multicolumn{3}{|c|}{$\begin{array}{l}\text { Esch.coli from outpatient } \\
\text { department subjected to } \\
\text { ESBL detection test }\end{array}$} & \multirow{2}{*}{$\begin{array}{l}\text { Total } \\
\text { Isolate } \\
\mathrm{d} \\
\text { Esch. } \\
\text { coli } \\
(\%)\end{array}$} & \multirow{2}{*}{$\begin{array}{l}\text { Total } \\
\text { ESBL } \\
\text { Esch. } \\
\text { coli } \\
\text { detected } \\
\text { By E test } \\
(\%)\end{array}$} \\
\hline & $\begin{array}{l}\text { Positive } \\
(\%)\end{array}$ & Negative & $\begin{array}{l}\text { Total } \\
\text { IPD }\end{array}$ & $\begin{array}{l}\text { Positive } \\
(\%)\end{array}$ & Negative & $\begin{array}{l}\text { Total } \\
\text { OPD }\end{array}$ & & \\
\hline Screening & 27 & 0 & & 13 & 19 & & & \\
\hline test & & & 27 & & & 32 & 59 & 32 \\
\hline DDST & 13 & 14 & & 05 & 27 & & (100) & $(54.24)$ \\
\hline $\begin{array}{l}\text { E test } \\
\text { ESBL }\end{array}$ & $\begin{array}{l}\mathbf{2 2} \\
(81.48 \%)\end{array}$ & 05 & & $\begin{array}{l}\mathbf{1 0} \\
(31.25 \%)\end{array}$ & 22 & & & \\
\hline
\end{tabular}

$p<0.001$

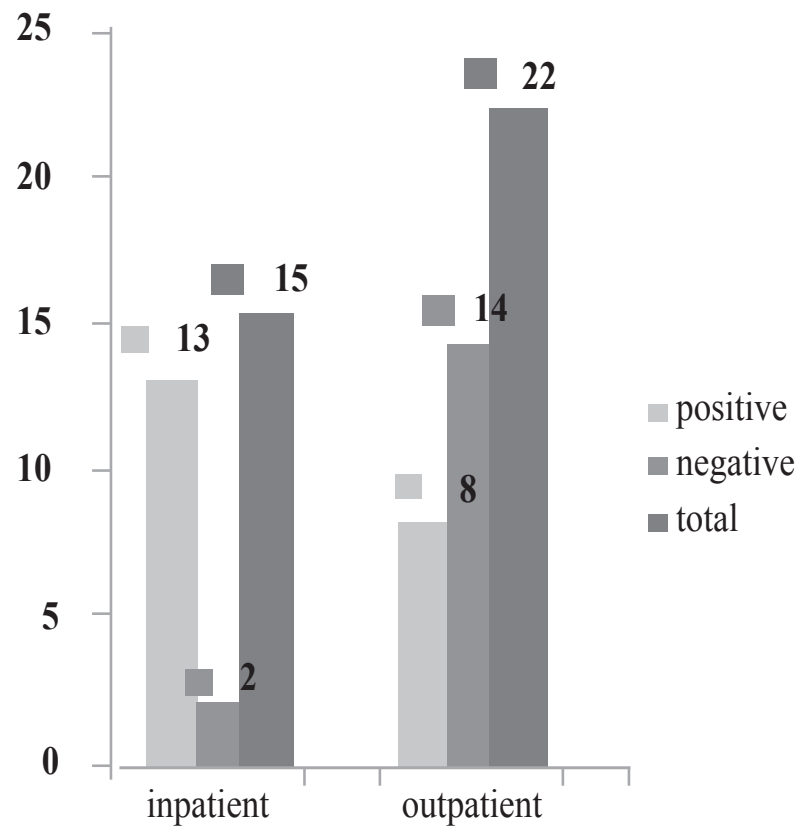

Figure 3: ESBL positive and negative Esch.coli in urine isolated from inpatient and outpatient department $(p<0.001)$

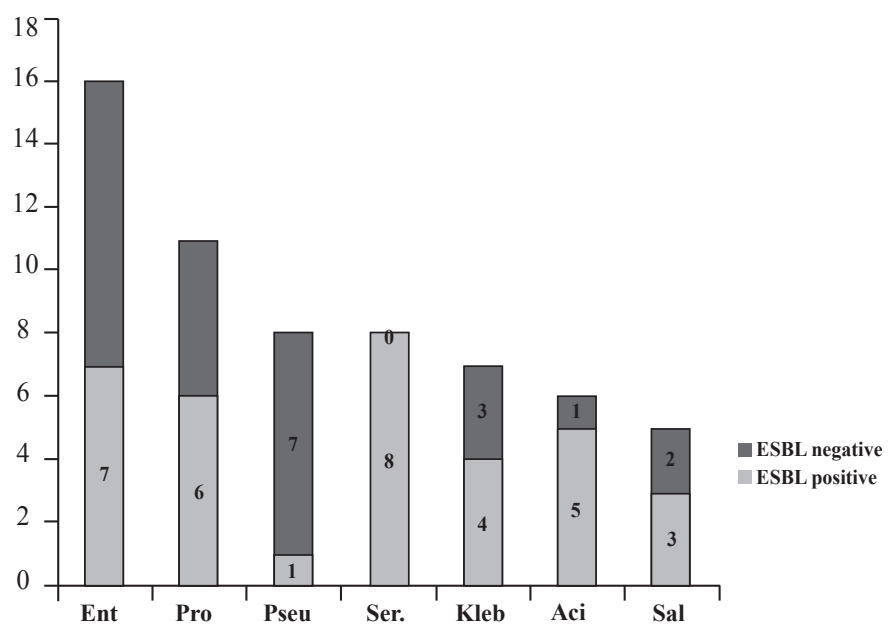

Figure- 4: The number of ESBL positive and ESBL negative isolates other than Esch.coli. 
Table 2: ESBL producing different bacteria detected by E test ESBL method

\begin{tabular}{|c|c|c|c|c|c|c|c|c|}
\hline \multirow{2}{*}{$\begin{array}{l}\text { Name of } \\
\text { bacteria } \\
\text { (n) }\end{array}$} & \multicolumn{3}{|c|}{$\begin{array}{l}\text { Inpatient department } \\
\text { isolates }\end{array}$} & \multicolumn{3}{|c|}{$\begin{array}{l}\text { Outpatient department } \\
\text { isolates }\end{array}$} & \multirow{2}{*}{$\begin{array}{l}\text { ESBLs } \\
\text { producers } \\
\text { out of total } \\
\text { ESBL(\%) }\end{array}$} & \multirow[b]{2}{*}{$p$ value } \\
\hline & $\begin{array}{l}\text { ESBL } \\
\text { Positive }\end{array}$ & $\begin{array}{l}\text { ESBL } \\
\text { Negative }\end{array}$ & $\begin{array}{l}\text { Total } \\
\text { IPD }\end{array}$ & $\begin{array}{l}\text { ESBL } \\
\text { Positive }\end{array}$ & $\begin{array}{l}\text { ESBL } \\
\text { Negative }\end{array}$ & $\begin{array}{l}\text { Total } \\
\text { OPD }\end{array}$ & & \\
\hline $\begin{array}{l}\text { Esch. coli } \\
(59)\end{array}$ & 22 & 05 & 27 & 10 & 22 & 32 & $32(54.24)$ & $<0.001$ \\
\hline $\begin{array}{l}\text { Enterobacter } \\
\text { spp. (16) }\end{array}$ & 07 & 07 & 14 & 00 & 02 & 02 & 07 (43.75) & $>0.05$ \\
\hline $\begin{array}{l}\text { Proteus spp. } \\
\text { (11) }\end{array}$ & 05 & 03 & 08 & 01 & 02 & 03 & $06(54.55)$ & $>0.05$ \\
\hline $\begin{array}{l}\text { Pseudomonas } \\
\text { spp(08) }\end{array}$ & 01 & 05 & 06 & 00 & 02 & 02 & $01(12.50)$ & $>0.05$ \\
\hline $\begin{array}{l}\text { Serratia } \\
\text { spp.(08) }\end{array}$ & 07 & 00 & 07 & 01 & 00 & 01 & $08(87.50)$ & - \\
\hline $\begin{array}{l}\text { Klebsiella } \\
\text { spp.(07) }\end{array}$ & 03 & 02 & 05 & 01 & 01 & 02 & $04(57.14)$ & - \\
\hline $\begin{array}{l}\text { Acinetobacter } \\
\text { spp.(06) }\end{array}$ & 05 & 01 & 06 & - & - & - & 05(83.33) & - \\
\hline $\begin{array}{l}\text { Salmonella } \\
\text { spp.(05) }\end{array}$ & 03 & 00 & 03 & 00 & 02 & 02 & $03(60.00)$ & - \\
\hline $\begin{array}{l}\text { Citrobacter } \\
\text { spp.(03) }\end{array}$ & 01 & 00 & 01 & 01 & 01 & 02 & $02(66.67)$ & - \\
\hline $\begin{array}{l}\text { Morganella } \\
\text { spp.(01) }\end{array}$ & 01 & 00 & 01 & - & - & - & $01(100.00)$ & - \\
\hline $\begin{array}{l}\text { Total Bacteria } \\
\text { (124) }\end{array}$ & 55 & 23 & 78 & 14 & 32 & 46 & $\begin{array}{l}69 \\
(55.65)\end{array}$ & - \\
\hline
\end{tabular}

\section{Discussion:}

Over the years beta lactams antibiotics are prescribed for both community acquired and hospital acquired infections. The continued use of these antibiotics produces selective pressure for pathogenic and commensal bacteria to produce and maintain beta lactam antibiotic destroying mechanisms. Discovery of different types of beta lactamase enzymes are the best example of this long continued pressure. Now a day's multiple broad-spectrum beta lactamases produced by multidrug-resistant $K$. pneumoniae, Acinetobacter spp., $P$. aeruginosa, and Enterobacter spp. have disseminated throughout gram-negative pathogens ${ }^{10}$.

In this research work ESBL producing isolates were identified from clinical specimens of outpatient (OPD) and inpatient department (IPD).ESBL strains obtained from outpatient department figured out community involvement. In contrast, ESBL infections of inpatient department denoted nosocomial or community participation. This study reported 32 (54.24\%) ESBL Esch.coli out of total 59 Esch. coli, in which $81.48 \%$ was from inpatient department and $31.25 \%$ from the outpatient department. Significant presence of higher percentage of ESBL producing Esch. coli in inpatient department in present study indicates certain degree of nosocomial spread of infections. Significantly higher number of ESBL producing Esch. coli was detected from urine of inpatient department which is consistent with findings of several studies ${ }^{6,11,12}$. Isolated $43.75 \%$ of Enterobacter spp, $54.55 \%$ of Proteus spp., and 57.14\% of Klebsiella spp were ESBL producers. Vinodhini et al., found low percentage of ESBL Enterobacter spp. and Proteus spp and Sridor et al., (2008) showed higher percentage of ESBL Proteus spp ${ }^{13,14 .}$
ESBL Enterobacter spp, ESBL Proteus spp and ESBL Klebsiella spp isolation numbers were high in IPD than OPD though statistically not significant.Other gram negative members could not be compared for significance test as number of isolated bacteria was very small. Identification of ESBL Acinetobacter spp was very important because this is one of the multidrug resistant pathogens ${ }^{10}$ and now a day it is being isolated from various biological specimens. This study also documented ESBL Pseudomonas spp from IPD samples as reported by other study ${ }^{14}$.Isolations of ESBL Acinetobacter (7.24\%) and ESBL Pseudomonas strains (1.45\%) were alarming because they are environmental bacteria, difficult to $\mathrm{control}^{8}$. All isolated Serratia spp were identified from IPD blood samples sent for blood culture and all of them were ESBL producers. Serratia infections are clearly related to hospitalization ${ }^{9}$. Comparable findings were documented by other studies ${ }^{15,16,17}$.

The present study reveals significant number of ESBL producing gram negative bacteria which demands routine practice of ESBL testing in microbiology laboratory of SSMC for reporting.

\section{References:}

1. Balan K. Detection of extended spectrum $\beta$-lactamase among gram negative clinical isolates from a tertiary care hospital in South India. Int J Res Med Sci 2013 ;(1):28-30.

2. Bush, K., G. A. Jacoby, and A. A. Medeiros. 1995. A functional classification scheme for beta-lactamases and its correlation with molecular structure. Antimicrob. Agents Chemother1995; 39:1211-1233.

3. Paterson DL. and Robert A. Bonomo. Extended-Spectrum $\beta$-Lactamases: a Clinical Update. Clinical Microbiology Reviews 2005;18 (4): 657-686.

4. Fatna Bourjilat, Brahim Bouchrif, Noureddine Dersi, Jean David Perrier Gros Claude, Hamid Amarouch, Mohammed Timinouni. Emergence of extended- spectrum betalactamase-producing Escherichia coli in communityacquired urinary infections in Casablanca, Morocco. J Infect Dev Ctries 2011; 5(12):850- 855.

5. Karen Bush and George A. Jacoby. Updated Functional Classification of $\beta$ - Lactamases. Antimicrob. Agents Chemother 2010; 54(3):969.

6. Gopal Kashyap, Sweta Gupta, Ved Prakash Mamoria, Pushpa Durlabhji, Dinesh Jain. Increasing Prevalence of Extended spectrum beta lactamases(ESBLs) Producing E.coli and Klebsiella spp in Outpatient Departments (OPDs) Patient in Urinary tract infections(UTIs) in Tertiary care Hospital. Int J Cur Res Rev 2013; 05(11) 80-86. 
7. Karen C. Carroll. Enteric Gram-Negative Rods. In: Geo.F.Brooks, Karen C. Carroll, Janet S.Butel, Stephen A. Morse and Timothy A. Meitzner editors. A Lanze Medical Book Jawetz, Melnick \& Adelberg's Medical Microbiology, 26 th ed. Mc Graw Hill Lange New York Chicago San Francisco Lisbon London Madrid Mexico City Milan New Delhi San Juan Seoul Singapore Sydney Toronto Inc; 2010 :pp 229.

8. Dhillon Rishi H.P. and Clark John. ESBLs: A Clear and Present Danger? Critical Care Research and Practice. 2012; Article ID 625170, 11 pages web page at: http://www.hindawi.com/journals/ccrp/2012/625170/ [Accessed on 15 April 2011].

9. Rahman NMW. Detection of CTX-M gene in extended spectrum $\beta$-lactamase (ESBL) producing Escherichia coli and Klebsiella species of different hospitals [M.Phil Thesis] Dhaka: Department of Microbiology, Sir Salimullah Medical College, The University of Dhaka; 2009:p. 114.

10.Karen Bush. Bench-to-bedside review: The role of $\beta$ lactamases in antibiotic- resistant Gram-negative infections. Bush Critical Care 2010:224. http://ccforum.com/content/14/3/224

11.Johann D D Pitout, Kevin B Laupland. Extended-spectrum $\beta$-lactamase- producing Enterobacteriaceae: an emerging public-health concern. Lancet Infect Dis 2008; 8: 159-66.

12.Simon Auer, Alexandra Wojna and Markus Hell. ESBL Producing Escherichia coli in ambulatory Urinary Tract Infections - Oral Treatment Options. AAC Accepts, published online ahead of print on 28 June 2010. Antimicrob Agents Chemother. doi:10.1128/AAC.01760-09.
13.Sridor Rao P N, Basavarajappa K G, Krisna G L, Detection of extended spectrum beta-lactamase from clinical isolates in Davangere. Indian J Pathol Microbiol 2008;51:497-499.

14.Raja Vinodhini, Kannaiyan Moorthy,Periyannan Palanivel, Thambidura Punitha, Selvam Saranya, Murugesan Bhuvaneshwari, Chinasamy Kanimozhi. Detection and antibiotic susceptibility pattern of ESBL producing Gram negative Bacteria. Asian Journal of Pharmaceutical and clinical research 2014;7(1):243-247.

15.Altun, Tufan ZK, Yac S, Önde U, Bulut C . Extended Spectrum Beta lactamases, AmpC and Metallo Betalactamases in Emerging Multi-drug Resistant Gramnegative Bacteria in Intensive Care Units. Open access scientific reports online. online Volume 2, Issue 4, 2013 2: 707 . A v a i lable from http://dx.doi.org/10.4172/scientificreports707

16.Amita Jain,Indranil Roy, Mahendra K. Gupta, Mala Kumar and S. K. Agarwal. Prevalence of extendedspectrum $\beta$-lactamase-producing Gram-negative bacteria in septicaemic neonates in a tertiary care hospital. J Med Microbiol 2003; 52 (5) 421-425.

17.Jena J, Debata NK, Subudhi E. Prevalence of extendedspectrum-beta- lactamase and metallo-beta-lactamase producing multi drug resistanc gram-negative bacteria from urinary isolates. Indian $\mathrm{J}$ Med Microbiol 2013;31:420-1. 